\title{
Determination Of Formaldehyde In Tofu From Ciputat Traditional Market With Colorimetry Method
}

\author{
Zilhadia and Sanny Susanti \\ Study Program of Pharmacy Faculty of Medicine and Health sciences \\ Syarif Hidayatullah State Islamic University \\ J1. Ir. H. Juanda No. 95 Ciputat Jakarta 15142
}

\begin{abstract}
Tofu, a food product made from soybean, contain water and it is very easy to overgrown microbes. Based on a survey, many products of tofu contain formaldehyde as preservative. Formaldehyde is a preservative that the use is prohibited for food because it can cause cancer in humans. The aim of this study was determined concentration of formaldehyde in tofu from traditional market Ciputat using Spectrophotometer UVI-VIS. Steam distillation was used for sample extraction process. Distillate was reacted with Nash reagent. The equation of calibration curve is $y=0,0032 x-0,0079$ and correlation coefficient of the linear regression of 0,9992 . The experimental results obtained LOD value of $11.1328 \mu \mathrm{g} / \mathrm{ml}$, LOQ value of $37,1094 \mu \mathrm{g} / \mathrm{mL}$ The precision of this analytical method were lower than $2 \%$ for each of the sample, while method's accuration for tofu was $98,69 \% \pm 0,4085 \%$. Results of sample analysis from Ciputat market, samples were detected containing formaldehyde. Formaldehyde concentrations are $104,87 \mu \mathrm{g} / \mathrm{mL}, 11,21 \mu \mathrm{g} / \mathrm{mL}, 1,96 \mu \mathrm{g} / \mathrm{mL}, 190,80 \mu \mathrm{g} / \mathrm{mL}, 201,98 \mu \mathrm{g} / \mathrm{mL}, 10,47$ $\mu \mathrm{g} / \mathrm{mL}$, and $3,31 \mu \mathrm{g} / \mathrm{mL}$.
\end{abstract}

Keywords: Formaldehyde, Spectrofotometry UV-Vis, Tofu, Nash reagent.

\section{INTRODUCTION}

Formaldehyde, $\mathrm{CH}_{2} \mathrm{O}$ is colorless tang gas that can be used as stabilizer with $15 \%$ metanol. (Dir. Jen. POM., 2003 ; Winarno, 2007). An aqueous solution of formaldehyde can be useful as a disinfectant as it kills most bacteria,fungi and viruses. It is also used as a preservative in cosmetics and a nail hardener in a concentration $<1 \%$. Formaldehyde preserves or fixes tissue or cells and used as embalming agent. (Dreisbach, 1982).

A number of surveys and laboratory examination found that several food product used formaldehyde as preservative. Some of them circulated in traditional market are salted fish, fresh fish, wet noodles and tofu ( Dir Jen POM, 2003). Formaldehyde is used to extend storage time. The interaction of formaldehyde and protein in food produces a solid elatstic texture of the food like wet noodle, fresh fish and tofu. Many consument like this texture of the foods. The smell of food containing formaldehyde is hated by fly and they dont want to perch. This longer storage time can provide benefit for both producent and consument. The high price of diesel fuel and ice blocks are other reasons why sailors use formaldehyde as preservative for their fresh fishes. (Suwahono, 2009).

Formaldehyde can be toxic and hazardous for human. The toxic effect willnot be appeared directly but manifested after years after the concentration of formaldehyde is accumulated in the body. Fatal dose of formaldehyde is $60-90 \mathrm{~mL}$ (Dreisbach, 1982). Tolerated dose for human body is $0.2 \mathrm{mg} / \mathrm{kg}$ body mass. (Anonim, 2006 ; Dir. Jen. POM., 2003).

BPOM (Drug and Food Inspection State Agency) has issued warnig no. KH.01.04.53.094 on 24 July 2007 about Chinese food product imports and domestics food products that contain hazardous substances. BPOM has taken sampel at some of markets and has conducted test of formaldehyde. The test has found out that these food products contain formaldehyde. Previous 
testing of 700 food products from Java, Sulawesi and Lampung conducted in 2002 is founded that $56 \%$ of sample contain formaldehyde.

There are 3 laws prohibit the use of formaldehyde, first UU no 7/1996 about food and UU no 8/1999 about consumer protection. The second one, minister of health regulations no. 1168/Menkes/PER/X/1999 states formaldehyde is a prohibited food additives. The thidr one,goverment regulations about regarding food safety dan nutritional quality no 28 on 2004 ( Depkes RI BPOM 2003).

Based upon those regulations, we conducted the research about determination formaldehyde content in tofu that circulated in Ciputat Market. Those tofu are suspected contain formaldehyde as preservative. We determined Ciputat market because it near from UIN Syarif Hidayatullah Campus and it is one of the big traditional market in Jakarta so that this research is purposed as UIN contribution to people around campus.

Determination of formaldehide contain in sample is conducted by colorimetry method, with Nash reagent which contain ammonium acetate, glasial acetic acid, acetyl aceton and water, as the reagent. As we know formaldehyde with acetyl aceton will condence to form a yellow 2,6-dimetil-3,5-diasetil-1,4-dihidropiridin compound. This compound has green flourecence color that can be detected in visible wave at $412 \mathrm{~nm}$.

\section{METHODOLOGY}

\section{Instruments}

Squash, distilation equipment, gas distilation equipment, measuring cups, erlanmeyer, thermometer, test tube,watch glass, metal spatula, analytical balance, alumunium foil,dissposable gloves, masks, petri dish, volumetric pipette, waterbath, UV-Vis spectrophotometer.

\section{Material}

Formalin (Merck) 37\% (water solution of formaldehyde), Ammonium acetate (Merck), Acetic acid glacial (Merck), acetyl acetone
(Merck), solution of $10 \%$ phosporic acid (Merck), soy bean, Calcium Sulphate/Sioko, Aquadest.

\section{Sample}

The samples are tofu from Ciputat traditional market that are taken randomly.

\section{Preparation of Tofu simulation}

Soybeans as much as $1 \mathrm{~kg}$ was washed by water, then soaked with water for approximately 5-6 hours. Soybeans crushed using a blender with added of warm water (soya and water ratio is $1: 2)$. Soybeans that was crushed was warmed to $70-80^{\circ} \mathrm{C}$ in the waterbath and filtered. Filtrat was warmed again and added $\mathrm{CuSO} 4$ until the blob was formed.Tofu is ready for the compacted.

\section{Measure of maximum wavelength.}

A solution of $1 \mathrm{ml}$ formaldehid $150 \mathrm{ppm}$ inserted to test tube and adjusted with water until $10 \mathrm{ml}$. The solution added Nash reagent $5 \mathrm{ml}$, and then kept at $37^{\circ} \mathrm{C}$ in waterbath for 30 menits. Mixtures moved to volumetric flask $25 \mathrm{ml}$ and adjusted with water until $25 \mathrm{ml}$, and shaked until homogeneus. Maximum wavelength was measured by UV-Vis spectrophotometer.

\section{Making Calibration Curve and Measured Linieritas.}

Making calibration curve is done by methods that was same as measure of maximum wavelength. Absorban of solution of formaldehid on a series of concentration was measured at the maximum wavelength.

\section{Limit of Detection (LOD) and Limit of Quantitation (LOQ)}

The limit of detectin was calculated using the formula

$$
\mathrm{LOD}=\frac{3,3(5 y / x)}{b}
$$

The Limit of Quantification was calculated using the formula:

$\mathrm{LOQ}=\frac{10 s y / x}{b}$

$\mathrm{Sy} / \mathrm{x}$ is standart deviasion 
$\mathrm{b}$ is slope of linier regression.

\section{Accuracy and Precision}

Tofu simulation crushed in mortar and then added formaldehyde concentration of $125 \mathrm{ppm}$ and inserted into the distillation flask. Into the distillation flask added $100 \mathrm{ml}$ water and $10 \mathrm{ml}$ of $10 \%$ phosphoric acid and then were distilled steam. Distillate collected into a $100 \mathrm{ml}$ erlenmeyer which already contains $10 \mathrm{ml}$ of water (end of the pipe dipped into distilled water) and were distilled until the distillate is obtained until a boundary. It was covered with aluminum foil and shake until a homogeneous. Then, concentration of formaldehid was measured. Performed the same way for formaldehyde content of $175 \mathrm{ppm}$ and $225 \mathrm{ppm}$. the value of accuracy and precision was calculated.

\section{Analysis of Samples}

For the analysis of samples out of the market Ciputat used the same method to measure out the simulation.

\section{RESULTS AND DISCUSSION}

Validation methods and determination of formaldehyde conducted using UV-Vis spectrophotometric method with the addition of Nash reagent. UV-Vis spectrophotometric method is a simple method. It can be used for determination of small concentrations. In addition, this method has its good sensitivity in the analysis process.

The maximum wavelength of solution of formaldehid which reacted with Nash Reagent is $412.73 \mathrm{~nm}$ (According to literature is 412-415). It can be seen at figure 1 .

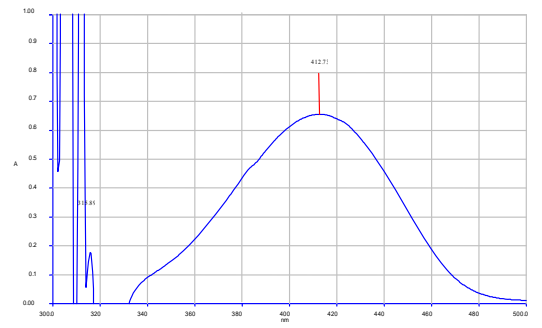

Figure 1. The maximum wavelength of solution of formaldehid which reacted with Nash Reagent
Solution of formaldehyde is a colorless solution. The compounds that can be measured absorbance with UV-Vis spectrophotometer is an organic compound that have a chromophore group and have a color. At the sample measurement process, solution of formaldehid is reacted with a reagent that could provide absorption spectrum of formaldehyde that is colored with Nash reagent. Nash reagent contains ammonium acetate, glacial acetic acid and acetyl acetone. When solution of formaldehid is reacted by Nash Reagent, it produces a steady yellow color (Jon, 1980; Nash, 1953).

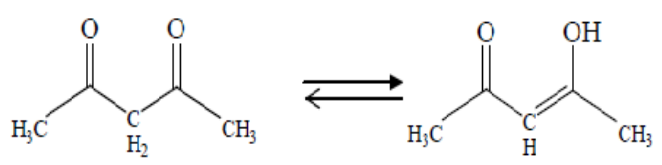

$$
\text { 2,4-Pentandion Bentuk enol }
$$

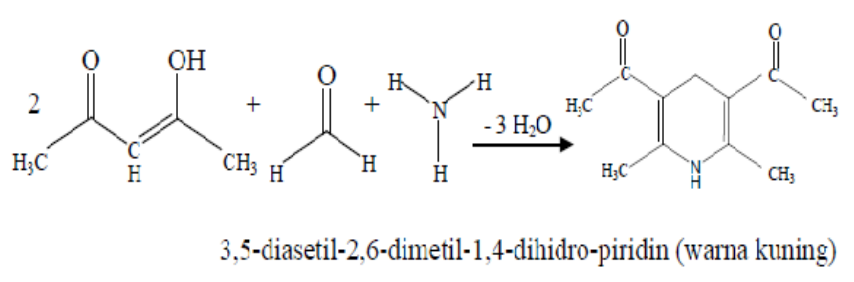

Sample extraction process is carried out by steam distillation. Steam distillation method performed because formaldehyde is a gaseous compound and is highly volatile or volatile. It has a boiling point $96^{\circ} \mathrm{C}$. Steam distillation is required to maintain the formaldehyde compound from being damaged, because the steam distillation is used to extract the compounds that do not withstand heat or high temperatures. Formaldehyde contained in the Tofu will be bound to proteins in the tofu. The addition of phosphate acid is intended to destroy or release the bond between formaldehyde with proteins so the formaldehyde can be separated by steam distillation process. The samples were prepared directly extracted using steam distillation temperature of $96^{\circ} \mathrm{C}$. Volumetric flask filled with aquadest $10 \mathrm{ml}$, and then submerged into the water cooler end. It aims to capture the formaldehyde vapor generated into the water distillation process that has been 
accommodated. After obtaining distillate $100 \mathrm{ml}$, distillation process was stopped.

The objective of validation of an analytical method is to demonstrate that the procedure, when correctly applied, produces results that are fit for purpose. Validation of analytical method begins by making the calibration curve and determination of linearity. Calibration curve is the relationship between the absorbance value of the analyte to the concentration of the analyte. The linearity is the ability of analytical procedure to produce test results which are proportional to the concentration (amount) of analyte in samples within a given concentration range, either directly or by means of a well-defined mathematical transformation. The value of correlation coefficient (r) is good if it is 0.999 . This means increasing the value of the analyte absorbance is directly proportional and significantly with increasing concentration. calibration curve generated with the equation $\mathrm{Y}$ $=0.0032 \times-0.0079$ and correlation coefficient $(r)=0.9992$. Formaldehyde calibration curve in a series of concentration ( $\mathrm{ppm})$ against absorbance can be seen in Figure 2.

Limit of Detection (LOD) is the lowest analyte concentration in the samples can still be detected (Gholib, 2006). The experimental results obtained LOD value of $11.1328 \mu \mathrm{g} / \mathrm{ml}$. Limit of quantitation (LOQ) is the smallest quantity of analyte in the samples can still be determined by the method used and meet the criteria carefully and thoroughly. The LOQ values obtained of $37.1094 \mathrm{~g} / \mathrm{ml}$. The result of the calculation of LOD and LOQ can be seen in table 1 .

Table 1. The result of the calculation of LOD and LOQ

\begin{tabular}{|l|c|}
\hline$\sum(y-y)^{2}$ & 0,00042294 \\
\hline$S(y / x)^{2}$ & 0,00014098 \\
\hline$S(y / x)$ & 0,011875 \\
\hline LOD (Limit Of Detection) & $11,1328 \mu \mathrm{g} / \mathrm{ml}$ \\
\hline LOQ (Limit Of Quantitation) & $37,1094 \mu \mathrm{g} / \mathrm{ml}$ \\
\hline
\end{tabular}

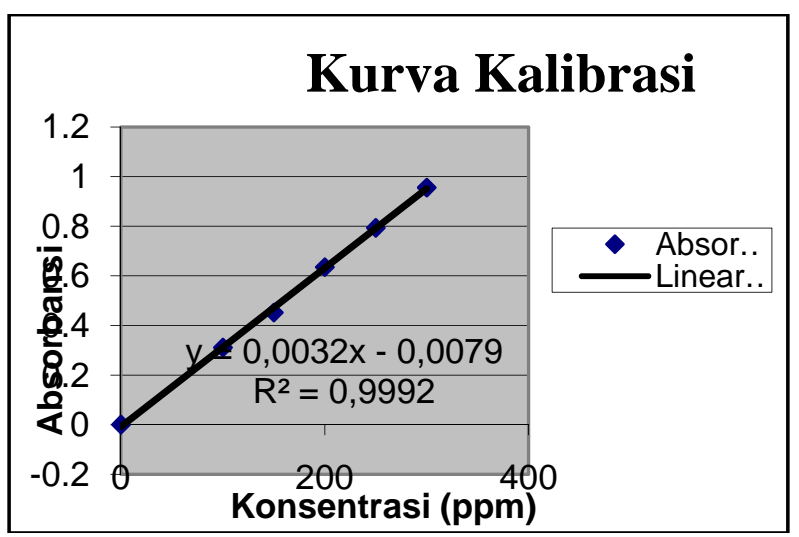

Figure 2. Formaldehyde calibration curve in a series of concentration (ppm) against absorbance

Accuracy is the closeness of the results obtained by determination of actual results and expressed in percent recovery. Percent recovery of three different concentrations of formaldehyde are $99.14 \%$ for the concentration of $125 \mu \mathrm{g} / \mathrm{ml}$, $98.59 \%$ for the concentration to $175 \mu \mathrm{g} / \mathrm{ml}$ and $98.36 \%$ for the concentration of $225 \mu \mathrm{g} / \mathrm{ml}$. The average of percent recovery is $98.69 \%$ with standard deviation (SD) of 0.4086 . Recovery test requirement is $98-102 \%$, so the results of this test meets the requirements. Results of Recovery test of formaldehyde in tofu simulation can be seen in table 2.

Table 2. Results of Recovery test of formaldehyde in tofu simulation.

\begin{tabular}{|c|c|c|}
\hline $\begin{array}{c}\text { Concentration } \\
(\boldsymbol{\mu g} / \mathbf{m l})\end{array}$ & $\begin{array}{c}\text { Percent of } \\
\text { Recovery }\end{array}$ & \multirow{2}{*}{$\begin{array}{c}\text { Average } \\
\mathbf{\pm S D}(\mathbf{\%})\end{array}$} \\
\hline 125 & 99,14 & \multirow{2}{*}{$98,69 \pm$} \\
\cline { 1 - 2 } 0,4085 \\
\hline 225 & 98,59 & \\
\hline
\end{tabular}

Results of precision test of formaldehyde in the tofu simulation can be seen in table 3 . 
Table 3. Results of precision test of formaldehyde in the tofu simulation

\begin{tabular}{|c|c|c|c|c|c|}
\hline $\begin{array}{c}\text { C (actual) } \\
(\mu \mathrm{g} / \mathrm{ml})\end{array}$ & $\begin{array}{c}\text { Means } \\
\text { UPK (\%) }\end{array}$ & $(x-x)$ & $\left((x-x)^{2}\right)$ & SD & KV \\
\hline 125 & 99,14 & 0,45 & 0,2025 & \multirow{4}{*}{0,4085} & \multirow{4}{*}{$0,4139 \%$} \\
\hline 175 & 98,54 & $-0,15$ & 0,0225 & & \\
\hline 225 & 98,36 & $-0,33$ & 0,1089 & & \\
\hline \multicolumn{2}{|c|}{$X=98,69$} & $\sum$ & 0,3339 & & \\
\hline
\end{tabular}

The standard deviation (SD) of data obtained at 0.4086 and coefficient of variation (CV) of $0.4139 \%$. Coefficient of variation requirement is $<2 \%$, so the results of this test meets the requirements. From these parameters, the method could be used for samples analysis obtained from traditional market Ciputat.

Results of Determination concentration formaldehid from traditional market Ciputat can be seen in Table 5.

Table 5. Results of Determination of formaldehid from traditional market Ciputat.

\begin{tabular}{|l|l|}
\hline Sample & Concentration $(\mu \mathrm{g} / \mathrm{ml})$ \\
\hline 1 & 104.87 \\
\hline 2 & 11.21 \\
\hline 3 & 1.96 \\
\hline 4 & 190.80 \\
\hline 5 & 201.98 \\
\hline 6 & 10.47 \\
\hline 7 & 3.31 \\
\hline
\end{tabular}

\section{SUMMARY}

1. The validation method of determination of formaldehyde in the Tofu with the colorimetric method can be done.
2. Results of sample analysis from Ciputat market, some samples were detected containing formaldehyde. Formaldehyde concentrations are $104,87 \mu \mathrm{g} / \mathrm{mL}, 11,21$ $\mu \mathrm{g} / \mathrm{mL}, \quad 1,96 \mu \mathrm{g} / \mathrm{mL}, \quad 190,80 \mu \mathrm{g} / \mathrm{mL}$, $201,98 \mu \mathrm{g} / \mathrm{mL}, 10,47 \mu \mathrm{g} / \mathrm{mL}$, and 3,31 $\mu \mathrm{g} / \mathrm{mL}$.

\section{ACKNOWLEDGMENT}

This research supported by Departement of Pharmacy, Faculty of Medicine and Health Science, UIN Syarif Hidayatullah Jakarta.

\section{REFERENCES}

1. Dir. Jen. POM. 2003. Formalin. Jakarta: Departemen Kesehatan RI. Hal: 3-20

2. Dreisbach, Robert H. 1982. Hand Book of Poisoning. Washington: University Of Washington. Hal: 200-201

3. Gandjar, Ibnu Gholib dan Abdul Rohman. 2009. Kimia Farmasi Analisis. Yogyakarta: Pustaka Pelajar. Hal: 18-19;199;456-474

4. Harmita. 2006. Analisa Fisikokimia .UI Press. Jakarta. 2006;17, 144-152

5. Jon Compton, Bruce, et al. 1980. Jurnal of The mechanism of the reaction of the Nash and the Sawicki aldehyde reagent. Department of Chemistry, McGill University, 801 Sherbrooke St. W., Montreal, P.Q., Canada H3A 2K6.

6. Nash, T. 1953. Jurnal of The Colorimetric Estimation of Formaldehyde by Means of the Hantzsch Reaction. Air Hygiene Laboratory, Public Health Laboratory Service, Colindale Avenue, London, N.W. 9.

7. Suwahono, S.Pd, et al.2009 Jurnal Analisis Kualitatif Adanya Formaldehid Pada Mie Basah. Semarang: IAIN Walisongo.

8. Winarno, F.G.,Sulistyowati, Titi. Bahan Tambahan untuk Makanan dan Kontaminan. 
Pustaka Sinar Harapan. Jakarta. 1994; 104-105, 108.

9. Gosselin ER et al. Clinical Toxicology of Commercial Products: Acute Poisoning, 4th ed. Baltimore: The Williams and Wilkins Co, 1976, p. 166-67. 